\title{
POPYTOWE UWARUNKOWANIA KONKURENCYJNOŚCI MALYCH I ŚREDNICH PRZEDSIĘBIORSTW
}

\begin{abstract}
Streszczenie
Małe i średnie przedsiębiorstwa (MSP) w warunkach gospodarki otwartej napotykają bariery ekspansji na rynek światowy, wynikające z braku wyraźnej przewagi konkurencyjnej. Przewagi kosztowe nie mają trwałego charakteru, natomiast przewagi technologiczne są dostępne wybranym, bardzo dużym i nowoczesnym korporacjom. Wobec tego, jako problem badawczy przyjęto ograniczoną zdolność MSP do konkurowania na rynku zagranicznym. Wydaje się, że w przypadku producentów żywności odpowiednią strategią konkurencyjną może być wyróżnienie oferty połączone z koncentracja (na segmencie lub produkcie). Pozwoli to kierować ofertę do konkretnych odbiorców, preferujących: jakość, naturalny charakter, walory zdrowotne, oryginalny smak, wyjątkowość konsumowanych dóbr. Przesłanką tej hipotezy jest tzw. etnocentryzm konsumencki.

Celem analizy jest weryfikacja hipotezy o trafności wyboru strategii wyróżnienia i koncentracji bazującej na jakości produktów żywnościowych. Analiza ta przede wszystkim opiera się na studiach literaturowych oraz dostępnych badaniach empirycznych. Jej wyniki świadczą o wrażliwości konsumentów na jakościowe parametry żywności oraz wiarygodności producentów budowanej na ich lokalnym charakterze i wysokiej rozpoznawalności.
\end{abstract}

Słowa kluczowe: strategie konkurowania, postawy konsumentów, etnocentryzm konsumencki

\section{DEMAND-RELATED DETERMINANTS OF COMPETITIVE POSITION OF SMALL AND MEDIUM-SIZED ENTERPRISES}

\begin{abstract}
Summary
In an open economic environment, small and medium-sized enterprises (SMEs) face numerous barriers to expansion onto the global market due to the absence of a clear competitive advantage. Cost advantages do not have a permanent character, and technological advantages are available to the select few, especially very large and modern corporations. Therefore, the adopted research problem is the limited ability of SMEs to compete on foreign markets. In the case of food producers, making one's products distinct from those of the competitors, combined with concentration (on segment or product) seems an appropriate competitive strategy. This makes it possible to direct the offer to specific consumers who appreciate the high quality, organic character, health benefits, original flavor and uniqueness of consumed goods. The premise of this hypothesis is the so-called consumer ethnocentrism.

The purpose of the analysis is to verify the hypothesis that it is worth choosing a strategy of distinction and concentration based on the quality of food products. The analysis is based primarily on literature studies
\end{abstract}

${ }^{1}$ Dr hab. Anna Chmielak, prof. UwB - Wydział Ekonomii i Zarządzania, Uniwersytet w Białymstoku; e-mail: annachmielak@gmail.com. 
and the available empirical research. The results indicate consumer sensitivity to food quality parameters and the reliability of producers built on their local character and high recognisability.

Key words: competition strategies, consumer attitudes, consumer ethnocentrism

\section{Wstęp}

Od dziesięcioleci rozwój regionów względnie zacofanych, określanych jako peryferyjne, stanowi ważne wyzwanie badawcze [Brodzicki, 2014; Zaucha, 2012]. Obserwacje prowadzone w rozwiniętych gospodarkach pokazują że mimo postępującego procesu umiędzynarodowienia i zwiazzanego z nim napływu inwestycji zagranicznych, rozwój sektora małych i średnich przedsiębiorstw pozostaje ważnym czynnikiem awansu cywilizacyjnego regionu [Damasiewicz, 2015]2. W tym kontekście warta uwagi staje się koncepcja rozwoju opartego na zasobach endogenicznych, w której obok czterech kluczowych ich grup, to znaczy: zasobów ludzkich, naturalnych, kapitału trwałego oraz finansowego, wyróżnia się zasoby niematerialne. Zalicza się do nich m.in.: wiedzę naukową technologiczna, informację, zaufanie odbiorców, konsumentów, potencjalny rynek wewnętrzny, normy i wartości pracowników oraz interesariuszy zewnętrznych. Na szczególną uwagę zasługuje zaufanie społeczne, jakim można objąć zarówno producentów, kooperantów, pośredników, organy decyzyjne, jak i społeczności lokalne [Pržedsiebiorstwa mysokiego wzrostu, 2014]3.

Relatywne opóźnienie rozwoju regionu łączy się z: niższą efektywnością gospodarowania zasobami, niższą koncentracją kapitału, efektywnością majątku i wydajnością pracy. Oznacza to, że istotnym warunkiem rozwoju regionu jest poprawa dynamiki sektora MSP [Præ̌edsięiorstwa wysokiego wærostu, 2014]4. Do oceny efektywności ekonomicznej systemów społecznych i gospodarczych można wykorzystać m.in. takie wskaźniki, jak: stopień koncentracji działalności gospodarczej, poziom rozwoju ekonomicznego, stopień efektywności majątku trwałego oraz poziom wydajności pracy5. Ich zastosowanie pozwala na sformułowanie wniosków w odniesieniu do rezultatów działalności gospodarczej w poszczególnych regionach.

W warunkach względnie wysokiej i pogłębiającej się liberalizacji stosunków międzynarodowych, w tym przepływu dóbr i czynników produkcji, uczestnicy działalności gos-

\footnotetext{
${ }^{2}$ Mikro, małe i średnie przedsiębiorstwa rodzinne, gospodarujące własnym kapitałem i relatywnie odporne na wahania na rynku światowym, są kluczowym czynnikiem rozwoju regionów peryferyjnych. Wskazują na to wyniki analizy zamieszczone w tekście: [Damasiewicz, 2015, s. 16-20]. Autorka zwraca uwagę na: niestabilność inwestorów zagranicznych, niejednoznaczne skutki wsparcia czerpanego z funduszy Unii Europejskiej, względnie wysokie koszty tworzenia miejsc pracy, ograniczony popyt na pracowników odnoszący się tylko do tych posiadających wysokie kwalifikacje.

${ }^{3}$ Interesującą i godną uwagi listę determinant rozwoju przedsiębiorstw prezentują autorzy analizy dynamiki firm wysokiego wzrostu. Zob. [Przedsiebiorstwa nysokiego wzrostu..., 2014].

${ }^{4}$ Badania pokazuja że tzw. przedsiębiorstwa wysokiego wzrostu to przede wszystkim firmy małe, rzadziej średnie, występujące we wszystkich sektorach i branżach. Ich obecność i aktywność w Polsce jest porównywalna $z$ tą w innych krajach. Może stanowią one motor wzrostu w takich regionach? Ciekawe rozważania i badania w tym zakresie sa zamieszczone w opracowaniu: [Przedsiębiorstwa wysokiego wzrostu w Polsce, 2014, s. 34 i nast.].

${ }^{5}$ Zajmujące i inspirujące poglądy w tym zakresie sa przedstawione w opracowaniu: [Łojewski, 2008, s. 116-132].
} 
podarczej zarówno konsumenci, jak i przedsiębiorcy znajdują się w sferze oddziaływania okoliczności w równej mierze sprzyjających, jak i ograniczających realizację indywidualnych oczekiwań. Możliwość pozyskania od podmiotów zagranicznych dóbr pośrednich, rozwiązań technologicznych i organizacyjnych, środków finansowych, odpowiednich zasobów pracy, surowców ułatwia funkcjonowanie na konkurencyjnym rynku i poprawę wskaźników efektywności. Podobnie oddziałuje dostęp do światowego rynku zbytu i kooperantów. Argumenty na rzecz liberalizacji rynku towarów i czynników produkcji są rozliczne i nie istnieje potrzeba ich przytaczania. Dyskusja nad tym toczy się od kilku wieków, raz faworyzując protekcję, a innym razem uwolnienie mechanizmu rynkowego od krępujących go regulacji. Weryfikatorem koncepcji naukowych jest praktyka gospodarcza, która jednak nie przynosi jednoznacznych rozstrzygnięć w tej kwestii. Otwarte pozostaje pytanie, czy poprawa międzynarodowej konkurencyjności przedsiębiorstw jest łatwiejsza do osiagania w warunkach liberalizacji wymiany międzynarodowej czy swoistej protekcji i wsparcia. Zdania sa podzielone.

Internacjonalizacja działalności gospodarczej staje się wymogiem chwili. Ani przedsiębiorstwa duże, ani średnie, ani korporacje nie mogą rozważać jako alternatywy autarkii, ponieważ nie jest to już niemożliwe. Funkcjonowanie w międzynarodowym, konkurencyjnym otoczeniu, tak w odniesieniu do przedsiębiorców, jak i konsumentów, wprowadza szereg ograniczeń i presji wynikających ze znacznie bogatszego, bardziej złożonego zbioru determinant realizacji celu. Presja ze strony konkurencji zawęża i utrudnia możliwość zajęcia i utrzymania korzystnej pozycji na rynku, wymuszając poszukiwanie specyficznych, oryginalnych źródeł przewagi konkurencyjnej. Jest to zadanie szczególnie trudne dla sektora MSP, w którym dla sporej części przedsiębiorców (mikro, małych, średnich) problemem może być ograniczona umiejętność generowania, wyboru oraz realizacji strategii rozwoju i konkurowania.

Z drugiej strony, z punktu widzenia konsumenta, korzyści z postępującego otwierania gospodarek, specjalizacji i liberalizacji wymiany międzynarodowej są łatwe do identyfikacji, o czym, od co najmniej dwóch stuleci, traktują rozważania wielu ekonomistów ${ }^{6}$. Konsumenci, mając znacznie bogatszą ofertę, są zmuszeni podejmować decyzje w warunkach względnie ograniczonego dostępu do informacji i niepełnej, czasem mało rzetelnej, wiedzy na temat parametrów jakościowych poszczególnych składników oferty. Można sądzić, że będzie to ich skłaniać - a przynajmniej tę bardziej wymagającą ich część - do poszukiwania takich dóbr, których parametry jakościowe nie budzą wątpliwości, a wiedza o nich jest satysfakcjonująca, relatywnie obszerna i wiarygodna. Do takich dóbr można zaliczyć żywność oraz trwałe dobra konsumpcyjne.

W takiej postawie konsumentów przedsiębiorcy mogą upatrywać przesłanki i podstawy budowania trwalej przewagi konkurencyjnej. Dotyczy to szczególnie mikro, małych i średnich przedsiębiorstw. Wypracowanie i wzmocnienie przez nie pozycji na rynku jest możliwe dzięki wykorzystywaniu naturalnych skłonności konsumentów do preferowania dóbr i usług: niebudzących wątpliwości, godnych zaufania, sprawdzo-

${ }^{6}$ Można powołać się na klasyczne koncepcje korzyści ze: specjalizacji produkcji, handlu międzynarodowego i swobodnego przepływu czynników produkcji [Łyżwa, 2014; Leśniewski, 2015; Misala, 2010; Zięba, Bieleń, Zając, 2015]. 
nych, obarczonych niskim ryzykiem [Międzynarodowa, 2006]. W niniejszym opracowaniu podjęto próbę weryfikacji takiej hipotezy, posiłkując się metodą studiów literaturowych oraz analizy dostępnych badań empirycznych.

\section{Podstawy konkurencyjności małych i średnich przedsiębiorstw}

Myśl ekonomiczna dotycząca uwarunkowań funkcjonowania podmiotów gospodarczych na rynku międzynarodowym jest bardzo bogata7. Istotną jej część stanowią koncepcje zawężania działalności w poszczególnych krajach i wyboru najkorzystniejszych kierunków specjalizacji ${ }^{8}$. Ewolucja poglądów w tym zakresie doprowadziła do sytuacji, w której można znakomitą część teorii przyporządkować bądź to uwarunkowaniom o charakterze podażowym, bądź popytowym. W praktyce te koncepcje nie wykluczają się nawzajem, ale raczej wspierają i uzupełniają w poszukiwaniu kierunków specjalizacji i podstaw korzyści z uczestnictwa w wymianie międzynarodowej. Jako uczestników rynku światowego rozumie się w nich albo gospodarki krajowe (ujęcie dominujące w początkowym okresie rozwoju ekonomii, w jej części odnoszącej się do makroekonomii), albo przedsiębiorstwa (podejście wprowadzone w okresie dominacji rozważań i ujęć mikroekonomicznych).

Popularność koncepcji neotechnologicznych od lat siedemdziesiątych XX wieku doprowadziła do zdominowania przez nie myślenia o sposobach objaśniania reguł konkurowania w warunkach: powszechnej otwartości gospodarek krajowych, postępu technologicznego, powszechności innowacji połączonej z liberalizacją przepływu: kapitału finansowego, rzeczowego oraz ludzkiego. Koncepcja luki technologicznej wskazuje na możliwość czerpania korzyści i znajdowania miejsca na rynku światowym zarówno przez liderów, jak i tych określanych mianem naśladowców bądź przedsiębiorstwa lokujące działalność gospodarczą w warunkach umożliwiających obniżanie jednostkowych kosztów produkcji. Zgodnie z nią, na otwartym rynku znajdzie się miejsce dla przywódców technologicznych (innowatorów), których korzyści są konsekwencją wdrażania nowości tak produktowych, jak i procesowych wąskiego grona odbiorców i możliwości utrzymania względnie wysokich cen (ceny nowości i elitarne grono odbiorców). Naśladowcy czerpią głównie korzyści ze: standaryzacji produkcji, jej masowego charakteru i dostępności gotowych rozwiązań technologicznych. Ta grupa przedsiębiorstw wprowadza towary na rynki różnych krajów, kierując je, po uprzednim dostosowaniu, do wielu zróżnicowanych segmentów rynku.

Trzecia grupa przedsiębiorstw może oferować na rynku światowym pełną bądź ograniczoną gamę dóbr, korzystając z dogodnych lokalizacji działalności - niższe ceny czyn-

\footnotetext{
7 Szczególne miejsce w niej zajmują te opracowania, które traktują o uwarunkowaniach wyboru i implementacji strategii rozwoju oraz te, które odnoszą się do strategii umiędzynarodowienia [Maćkowiak, 2013; Nowińska-Łaźniewska, 2013].

${ }^{8}$ Tę część dorobku myśli ekonomicznej można zaliczyć do klasyki, ponieważ dotyczy okoliczności wyboru kierunków specjalizacji na poziomie gospodarki, a nie poszczególnych przedsiębiorstw [np.: Ratajczak, 2012].
} 
ników produkcji, rentowne warunki w zakresie opodatkowania, chłonny rynek zbytu, sprzyjające warunki w otoczeniu instytucjonalnym9. Taki podział przedsiębiorstw jako biorców korzyści z umiędzynarodowienia działalności wyjaśnia podstawy i przesłanki obecności wielu producentów, zlokalizowanych w krajach o różnym poziomie rozwoju. Dodatkowymi źródłami korzyści staja się: podział i specjalizacja wewnątrzgałęziowa czy rozwijanie tzw. montażowni dóbr finalnych zaopatrujących się w dobra pośrednie u producentów z różnych krajów. W czołówce gospodarek czerpiących korzyści z takiej formy funkcjonowania na rynku światowym znajduja się chyba Chiny [Gierszewska, 2014; Szymański, 2015] ${ }^{10}$.

Jednakże koncepcje te nie rozwiązują kluczowych problemów małych i średnich przedsiębiorstw działających w regionach i krajach słabiej rozwiniętych, ponieważ napotykają one bariery wejścia istniejące w oligopolistycznej strukturze rynku międzynarodowego. Tylko w nielicznych krajach o gospodarce rynkowej (m.in.: Niemcy, Japonia) wsparcie ze strony państwa umożliwia tego typu przedsiębiorcom skuteczne i efektywne wchodzenie oraz funkcjonowanie na rynku światowym. W większości krajów, średni i mały biznes rodzinny nie jest w stanie spełniać wymogów konkurencji narzucanych przez oligopole i duże korporacje międzynarodowe. Strategie budowania przewagi konkurencyjnej, powszechnie przyjmowane jako kosztowe lub technologiczne, nie sa adekwatne do warunków, w jakich funkcjonuje ta grupa przedsiębiorstw. Ani przywództwo kosztowe, ani technologiczne, niezależnie od geograficznej lokalizacji działalności gospodarczej, nie stanowi przesłanki ich przewag konkurencyjnych i stabilnej pozycji na światowym rynku [Raport o stanie sektora..., 2015] ${ }^{11}$.

Wobec tego, w warunkach ograniczonej przydatności koncepcji podażowych - dotyczy to także koncepcji cyklu życia produktu oraz korzyści skali - wypada zastanowić się nad możliwością budowania przewagi opartej na koncepcjach wykorzystujących uwarunkowania po stronie popytu. Jedną z nich, w ramach tradycyjnych teorii korzyści z handlu i specjalizacji, jest koncepcja podobieństwa preferencji, a drugą różnicowanie produktu. Po wnikliwszym rozważeniu możliwości ich stosowania przez MSP okazuje się, że krytycznymi warunkami mogą być: skala produkcji i dostęp do odpowiednio chłonnych rynków zbytu. Wychodząc poza tradycyjne koncepcje korzyści z handlu i posiłkując się dorobkiem nauk o zarządzaniu w zakresie strategii rozwoju przedsiębiorstw, można przyjąć, że w odniesieniu do mikro, małych i średnich przedsiębiorstw moga mieć zastosowanie koncepcje budowania przewagi konkurencyjnej opartej na efektach kon-

\footnotetext{
${ }^{9}$ Szersze omówienie korzyści z wykorzystania koncepcji luki technologicznej do czerpania korzyści z obecności na rynku światowym można znaleźć w opracowaniach: [Leśniewski, 2015; Misala, 2010].

10 Mechanizm czerpania korzyści w takich warunkach opisuje np. Gierszewska [Gierszewska, 2014]. Część analityków zwraca uwagę na niską atrakcyjność takiej koncepcji rozwoju z powodu jej „odtwórczego", a nie nowatorskiego charakteru [np.: Szymański, 2015, s. 183-194].

11 Zarówno skala, dynamika, jak i odsetek eksportu polskich MSP względem produkcji nie są imponujące. Jak wynika z badań PARP, wielkości te wahaja się od kilku (w przypadku mikro przedsiębiorstw) do kilkunastu (w przypadku średnich) i kilkudziesięciu w stosunku do dużych przedsiębiorstw. Zob. [Raport o stanie sektora..., 2015, s. 30-31].
} 
centracji oraz wyróżnienia. Nie wydaje się, by mogły tu mieć zastosowanie przewagi pochodzące z: ekspansji geograficznej, innowacji lub przywództwa kosztowego ${ }^{12}$.

Według koncepcji K. Ohmae, strategie konkurencji, które przyczyniają się do poprawy pozycji konkurencyjnej, można podzielić na strategie polegajace na działaniach prowadzacych do wzrostu stopnia dostosowania oferty do potrzeb odbiorców i strategie polegające na dążeniu do zmian kluczowych czynników sukcesu. Do pierwszych należy koncentracja na kluczowych czynnikach sukcesu oraz maksymalizacja korzyści dla odbiorcy przez wykorzystanie strategicznych stopni swobody. Natomiast do drugich zalicza się dążenie do osiagnięcia relatywnej przewagi przy wykorzystaniu słabości rywali oraz podejmowanie działań agresywnych. W związku z tym, źródłem przewagi konkurencyjnej przedsiębiorstwa mogą być: koncentracja zasobów na wybranych, funkcjonalnych polach działania, czyli dążenie do osiagnięcia funkcjonalnej odmienności, właściwe uwzględnienie różnic w zasobach strategicznych, wykorzystanie słabości rywali, zmiana kluczowych czynników sukcesu i wdrażanie nowych produktów [Pierścionek, 2003, s. 266-267].

Podsumowując, w warunkach otwartych rynków światowych MSP są zmuszone budować i umacniać przewagę konkurencyjną, niezależnie od tego, czy aspirują do ekspansji na rynek światowy, czy maja jedynie ambicje regionalne i lokalne. Wymóg konkurencyjności jest powszechny, ponieważ oferta musi być konkurencyjna na rynku krajowym (lokalnym) wobec dóbr importowanych, a na rynku światowym wobec oferty innych producentów [Głód, 2015] $]^{13}$. Oczekiwanie wsparcia albo protekcji rządów krajowych lub organizacji międzynarodowych nie jest uzasadnione nie tylko z powodu ograniczoności budżetu i środków publicznych, ale przede wszystkim z tytułu regulacji prawnych i ochrony konkurencji. Aktywność MSP winna sprowadzać się do poszukiwania możliwości i warunków wyróżnienia oferty albo (i) koncentracji działalności na określonym segmencie rynku lub wyraźnie zdefiniowanym produkcie (usłudze). Jest to swoisty wybór konkurowania bazujący na specjalizacji (albo koncentracji) oraz wyróżnieniu [Raport o stanie sektora..., 2015] ${ }^{14}$. Przesłanką wyróżnienia oferty są preferencje konsumentów w odniesieniu do tzw. wrażliwych jakościowo dóbr konsumpcyjnych. W osiaganiu przewagi budowanej na korzyściach z koncentracji kluczowe jest skupienie się na zaspokajaniu potrzeb wąsko zdefiniowanych segmentów rynku albo asortymentu dóbr [Sawin,

\footnotetext{
12 Należy porównać rodzaje strategii rynkowych opisane przez Magrett i innych: [Magrett, 2014; Obłój, 2014; Rymarczyk, 2012, s. 574-577].

${ }^{13}$ Warto zwrócić uwagę na wyniki badań W. Głoda, które wskazują na to, że orientacja przedsiębiorcza ma kluczowe znaczenie w procesie umiędzynarodowienia MSP. Składają się na nią takie zmienne, jak: konkurencyjna agresywność, proaktywność i innowacyjność. Optymalne umiędzynarodowienie MSP wymaga wzmocnienia orientacji strategicznej w obszarze: produktów, rynków, ryzyka oraz zasobów. Zob. [Głód, 2015].

14 Polski eksport jest zdominowany przez eksporterów wyspecjalizowanych, czyli osiagających przychody z eksportu powyżej 50\% przychodów ogółem. Połowa eksportu $(48,1 \%)$ jest realizowana przez 3,1 tys. podmiotów szczególnie wyspecjalizowanych w eksporcie (18,7\% eksporterów), których eksport stanowi powyżej 75\% ich przychodów. Jedna tego typu firma osiaga przeciętnie 90 mln PLN przychodów z eksportu - pięć i pół razy więcej niż eksporterzy niewyspecjalizowani. Zob. [Raport o stanie sektora..., 2014, s. 34-36].
} 
$2015]^{15}$. W przypadku małych firm o rozwoju i poprawie konkurencyjności głównie decyduje znajomość rynku i potrzeb klientów. Stąd ich szanse są związane ze zorientowaniem na wybranego, wasko zdefiniowanego klienta, zaspokajaniem jego potrzeb oraz $\mathrm{z}$ takim wyborem niszy rynkowej, która nie jest atrakcyjna dla większych konkurentów (koncernów), [Marketing eksportony ..., 2014] ${ }^{16}$.

Przedsiębiorstwo powinno koncentrować się na kluczowych kompetencjach i przekazywać do wykonania na zewnątrz czynności, które nie odróżniaja go od konkurentów. Powinno tworzyć coraz silniejsze sieci powiązań z: klientami, dostawcami, instytucjami naukowymi i uniwersytetami, a nawet konkurentami [Przedsiebiorstwa aysokiego w₹rostu..., 2014] ${ }^{17}$. Innowacje stają się bowiem coraz bardziej kompleksowe, wymagające technologii oraz wiedzy z różnych: sektorów, gałęzi, branż, instytucji. Firmy poszukują w ten sposób wiedzy i komplementarnych kompetencji w celu ich koordynacji do realizacji finalnego produktu [Rymarczyk, 2012, s. 579-581]. Zmierzają one do lepszego od konkurentów zaspokojenia gustów konsumentów przez dostarczanie im produktów o wyższej jakości, bardziej zróżnicowanych i tańszych, a także wykreowania nowych potrzeb. Coraz większą rolę odgrywa dostosowanie produktów do indywidualnych potrzeb klientów, które można pogłębiać, włączając ich w proces projektowania.

Ważnym czynnikiem budowania konkurencyjności lokalnych produktów konsumpcyjnych jest zjawisko określane jako patriotyzm lokalny albo etnocentryzm konsumencki. Od ponad pól wieku są prowadzone badania w kierunku identyfikacji głównych determinant etnocentryzmu i rodzajów dóbr, jakich dotyczy ${ }^{18}$. Postrzeganie kraju staje się synonimem marki i może wpływać na decyzje zakupowe ${ }^{19}$. Wybór artykułów rodzimej produkcji może być podyktowany racjonalnymi przesłankami albo faworyzowaniem producentów krajowych. Jako przykład może posłużyć społeczeństwo niemieckie i francuskie. Jest ono wyjątkowo silnie związane z krajowymi markami, co oznacza, że preferuje produkty krajowe, a ich zakup jest w dobrym tonie, szczególnie w odniesieniu do takich

15 W objaśnianiu tych koncepcji fundamentalne znaczenie mają opracowania Portera [Porter, 2012; Porter, 2010]. Ponadto, ciekawie ujmuje to przedsiębiorca, wyjaśniając co cechuje mistrza w tej dziedzinie: (...) absolutne mistrzostwo w jednej, wasko zdefiniowanej specjalności, na która jest globalny popyt. I dalej (...) ujawnia sie ono w ciagtym dażeniu do ulepszania oferowanych produktów, pogtebiania istniejacej wiedsy i przęnaczaniu znacznych środków na prace B+R w obszarach, w których się konkuruje [Sawin, 2015, s. 38].

16 Autorzy zwracają uwagę na konieczność segmentacji, która umożliwi dostosowanie produktów do potrzeb nabywców, co przyczyni się do zwiększenia sprzedaży i konkurencyjności danych towarów na rynku, usprawni dotarcie do konsumentów, których preferencje są uwzględniane przy kształtowaniu produktu, zapewni efektywne wydatkowanie środków finansowych przeznaczonych na aktywizację sprzedaży przez odpowiedni dobór form promocji i akwizycji w stosunku do określonych i znanych adresatów, pozwoli dostrzec zmiany na rynku dzięki ciągłemu monitoringowi jego określonych segmentów i wcześniejszemu przygotowaniu się do ewentualnych zmian, ułatwi określenie czasu nasilania się aktywizacji sprzedaży spowodowanej działaniami informacyjno-promocyjnymi [Marketing eksportony..., 2014, s. 17].

${ }_{17}$ Interesujące wyniki badania warunków wysokiego wzrostu, w tym szeroko zdefiniowanych determinant o charakterze zewnętrznym, zawiera opracowanie: [Przedsiębiorstwa wysokiego wærostu..., 2014].

18 Charakterystyka badań oraz ich wyniki są dostępne są w źródłach elektronicznych, np.: [www.590powodow.pl; www.pwe.com.pl/files/1276809751/file/mir_04_2014_szromnik.pdf]. Zob. też: [Hereźniak, 2011, s. 65; Mruk, Stępień, 2013].

${ }^{19}$ Dobrym przykładem mogą być: samochody niemieckie lub japońskie, francuskie wina i kosmetyki, amerykańskie dżinsy. 
dóbr, które wykorzystuje się podczas pobytu za granica. Ważne jest to, że postawy etnocentryczne przede wszystkim zauważa się w odniesieniu do artykułów żywnościowych i trwałych dóbr konsumpcyjnych stanowiących swoisty wyraz prestiżu posiadacza ${ }^{20}$.

\section{Postawy konsumentów a strategie małych i średnich przedsiębiorstw}

Zagadnienia podjęte w tym opracowaniu skłaniają do badania postaw konsumentów i uwarunkowań ich decyzji w sferze zakupów oraz prowadzą do interesujących i ważnych spostrzeżeń i konkluzji. Odnoszą się one do wybranych dóbr, zaspokajających stosunkowo szeroki zakres podstawowych potrzeb konsumpcyjnych. W szczególności dotyczy to żywności ${ }^{21}$. Ponadto, ważne jest precyzyjne określenie strategicznego segmentu rynku, którego oczekiwania mogą być zaspokajane drogą przygotowania wyjątkowej oferty, posiadającej określone, ważne dla konsumenta cechy jakościowe. Warto zastanowić się nad kilkoma kwestiami, a mianowicie:

- $\quad$ czy preferencje w stosunku do żywności są związane z poziomem dochodów?

- jakie są przesłanki różnicowania oczekiwań wobec różnych grup towarów?

- jakich dóbr dotyczą wyraźne preferencje na rzecz jakości kosztem ceny?

- jakie są kluczowe argumenty na rzecz strategii wyróżnienia oferty?

Dochodowa elastyczność popytu jest dobrze rozpoznaną funkcją ekonomiczną. W przypadku nietrwałych dóbr konsumpcyjnych, w tym żywności, ekonomia zajmuje stanowisko dość jednoznaczne: ich znaczenie w krańcowych wydatkach konsumpcyjnych oraz wydatkach ogółem maleje. Nie wyczerpuje to jednak charakterystyki postaw konsumentów wobec cech poszukiwanych w dobrach zaspokajających te, niby marginalne potrzeby. Jeśli posłużyć się wynikami badań preferencji konsumentów, to okaże się, że względnemu zmniejszaniu się znaczenia parametrów ilościowych towarzyszy istotny wzrost wagi jakościowych parametrów żywności. Zależność jest dodatnia, ponieważ rosnącym dochodom i wyższemu poziomowi życia towarzyszy wzrost znaczenia cech jakościowych. Konsumenci preferują żywność mało przetworzona, z ograniczoną zawartością składników chemicznych, wytwarzaną w warunkach zbliżonych do naturalnych, cechującą się tradycyjną receptura, smakiem i składnikami [Tendencje zachowań..., 2010] $]^{22}$. Wysoko towarowa produkcja w rolnictwie, tak charakterystyczna na etapie industrializa-

20 Warto zauważyć, że nasilenie się preferowania dóbr krajowych wiąże się nie tylko z ich przeznaczeniem (żywność), ale także z poziomem dochodów konsumentów. Wyraźna jest rosnąca skłonność do nabywania dóbr krajowych i lokalnych, towarzysząca wzrostowi poziomu dochodów gospodarstw domowych [Florek, 2013].

${ }^{21}$ Konsumpcję żywności cechuje specyfika podyktowana tym, że jedzenie jest bezpośrednio związane z podstawowymi potrzebami życiowymi jednostki, a nawyki żywieniowe są konsekwencją złożonych procesów: biologicznych, historycznych i kulturowych. Jest to najbardziej złożona forma konsumpcji i kluczowy przejaw wpływu czynników subiektywnych o podłożu psychologicznym.

22 Jako najważniejsze powody zakupu żywności ekologicznej wskazuje się dbałość o zdrowie czy eliminację z niej konserwantów i związków chemicznych. Obok nich, ważne są: troska o stan środowiska naturalnego, preferencja dobrego smaku i walory lecznicze. Rozważania i wyniki badań na ten temat zawarto w opracowaniu: [Tendencje zachowań konsumenckich..., 2010]. 
cji, schodzi na dalszy plan, ustępując miejsca produkcji prowadzonej w warunkach zbliżonych do naturalnych, $z$ wykorzystaniem: tradycyjnych technologii produkcji, naturalnych nasion, typowych dla danych regionów roślin, ras zwierząt, regionalnych sposobów obróbki i przetwórstwa płodów rolnych ${ }^{23}$.

Wraz ze wzrostem gospodarczym rośnie poziom dochodów i liczebnie poszerza się segment konsumentów zainteresowanych cechami jakościowymi. Grupa ta preferuje dobra szczególnego rodzaju, których wytwarzaniem nie zajmują się duże przedsiębiorstwa nastawione na konsumpcję masową i dobra standardowe. Jest to szansa dla mikro, małych i średnich przedsiębiorstw, których skala działalności zapewniająca rentowność nie jest duża, a stosowane techniki i metody produkcji sa bliższe tradycyjnym. Mała skala i lokalny charakter mogą również stanowić gwarancję świeżości produktów [ŻakowskaBiemans, 2012, s.7-10, s. 14-16].

Przesłanką różnicowania oczekiwań konsumentów w stosunku do cech jakościowych żywności jest głównie troska o stan zdrowia. W opinii coraz większej liczby konsumentów, wysoki stopień przetworzenia, wykorzystywanie środków chemicznych na każdym etapie procesu produkcyjnego i przetwórstwa, względnie wysoki udział różnych syntetyków, zamiast surowca naturalnego, w gotowych artykułach żywnościowych stanowi podstawę dyskwalifikacji składników tego rodzaju oferty. Wymagania konsumentów rosną w odniesieniu do tej części dóbr, które są przeznaczone dla dzieci, osób starszych, obciążonych bądź zagrożonych różnego rodzaju dolegliwościami i chorobami. Postęp cywilizacyjny pociaga za sobą wzrost świadomości konsumentów i podnosi wymagania wobec dóbr przeznaczonych do bezpośredniego spożycia, szybko rotujących i stale nabywanych.

Przewaga kryterium jakości kosztem kryterium niskiej ceny dotyczy zarówno grup towarów, jak i segmentów rynku. Jeśli uwzględnić to w poszukiwaniu podstaw przewagi konkurencyjnej, to okaże się, że większość międzynarodowych koncernów funkcjonujących w obszarze produkcji i przetwórstwa żywności nie będzie stanowić silnej konkurencji wobec małych i średnich, głównie lokalnych przedsiębiorców ${ }^{24}$. Ważne jest, by przedsiębiorcy potrafili opanować sztukę wyróżnienia swojej oferty, dotarli z nią do konsumentów, a ci wykazali zainteresowanie i ją zaakceptowali.

Strategia wyróżnienia oferty wymaga trafnego rozpoznania oczekiwań konsumentów. Jej stosowanie nie sprowadza się do nadania produktom cech wyjątkowych, których nie mają dobra innych producentów. Kluczowe jest nadanie wyrobom dokładnie

\footnotetext{
${ }^{23}$ Regionalne bądź lokalne pochodzenie artykułów żywnościowych, produkowanych dzięki tradycyjnym metodom, staje się atrakcyjną alternatywą wobec modelu masowej konsumpcji i jednorodnej żywności. Tradycja i lokalny patriotyzm są często eksponowane w marketingu dóbr spożywczych. Łączy się to z odwoływaniem się do lokalnej tradycji, a postrzeganie autentyczności produktu wytwarzanego według naturalnych receptur i metod jest zwiazane z: miejscem, tradycją i historia.

${ }^{24} \mathrm{~W}$ badaniach rynku i określaniu perspektywicznych, strategicznych segmentów odbiorców koncerny marginalizują osoby starsze, pomijają je w badaniach, traktując jako mniej ważne, schyłkowe segmenty rynku. Być może, pomijanie tej grupy klientów również wiąże się z silną presją na standaryzację dóbr czy łatwość ich promowania wśród stosunkowo młodych nabywców. Tymczasem udział grupy osób starszych w ogóle ludności będzie zwiększał się, a ich dochody nie należą do najniższych, nawet w krajach transformujących się.
} 
takich cech jakościowych, jakie są ważne dla konsumentów, których oni poszukują i preferują podczas zakupu. Małym i średnim, lokalnym przedsiębiorcom jest łatwiej poznać te oczekiwania i czynić skuteczne starania na rzecz przygotowywania odpowiedniej oferty [Etnocentryzm konsumencki..., 2014] ${ }^{25}$. Jest to wysiłek, który przyniesie oczekiwane efekty, pod warunkiem bliskiej współpracy i ciagłych kontaktów z konsumentami. W tym przypadku względnie mała skala działalności w początkowym okresie i bliskość geograficzna sprzyja powodzeniu przedsięwzięcia. Z czasem zasięg geograficzny działalności może być poszerzany, ponieważ na sąsiednich rynkach również znajdują się konsumenci zainteresowani właśnie takimi cechami dóbr. Oferta może być sukcesywnie przenoszona na inne segmenty rynku, co pociagnie za sobą dodatkowe korzyści skali [Zob. Etnocentryzm konsumencki..., 2014].

Wypada odnotować, że obecne trendy na rynku żywności wskazują na zasadność forsowania strategii wyróżnienia i koncentracji. Jako najistotniejsze z nich zauważa się następujące: personalizację żywności (bardzo wąsko i wyraźnie określony odbiorca), przygotowywanie posiłku w domu z wykorzystaniem naturalnych składników, regionalizm (tradycje regionalne w żywieniu i przygotowaniu posiłków), zdrowie, smak, prostota [www.erov.be/documenten/gazdecki_goldmann.ppt]. Na polskim rynku jest zauważalny: regionalizm, tradycjonalizm, wyjątkowość smaku. Rośnie znaczenie jakości w powiązaniu z miejscem pochodzenia, a jest to ważne w przypadku zamożnych konsumentów. Identyfikacja miejsca pochodzenia towaru nie stanowi problemu, konieczne jest uzupełnienie go o wiarygodne cechy wyróżniające (np.: tradycyjne metody uprawy i żywienia, naturalne, ekologiczne sposoby przechowywania i przygotowania produktów przeznaczonych do indywidualnego spożycia), [Szromnik, Wolanin-Jarosz, 2014]26.

Wydaje się, że zarówno założenia, jak i praktyka w zakresie wyróżnienia oferty są odpowiednie dla tych przedsiębiorców, którzy funkcjonują na rynkach lokalnych, wśród znanych sobie segmentów rynku. Bliskość geograficzna, przestrzenna i kulturowa pozwala przypuszczać, że wyróżnione tu cechy popytu mogą stanowić przesłankę strategii rozwoju i konkurowania MSP funkcjonujących w regionach położonych w obszarach przygranicznych Polski i jej sąsiadów [Wolanin-Jarosz, 2015, s. 29-41]. Wspólna historia, podobieństwo kulturowe, tradycje są czynnikami ułatwiającymi podejmowanie wspólnych przedsięwzięć gospodarczych przez podmioty znajdujące się po obu stronach granicy. Porozumienia sieciowe w sektorze MSP czy struktury klastrowe forsuje się jako sposób na identyfikację: specyfiki dóbr, wizerunku producenta i jego tożsamości wśród konsumentów zamieszkujących sąsiednie kraje. Niech to stanowi punkt wyjścia w poszukiwaniu strategii konkurowania MSP we względnie zacofanych, przygranicznych obszarach Polski i jej sąsiadów.

25 Dystrybucja zdrowej żywności wymaga: krótkich kanałów, ograniczonej liczby pośredników, szybkiej rotacji i zapewnienia różnorodności asortymentu oraz gwarancji świeżości. Wybrane badania na ten temat zwarto w opracowaniu: [Etnocentryzm konsumencki na rynku produktów sisnnościonych. Stan i perspektyny rozwoju, 2014].

${ }^{26}$ Syntetyczne rozważania na ten temat są zawarte w pracy: [Szromnik, Wolanin-Jarosz, 2014]. 


\section{Podsumowanie}

Rozważania przeprowadzone w niniejszym opracowaniu wskazują na możliwość pozytywnej weryfikacji hipotezy. Oznacza to, że punktem wyjścia w rozwoju sektora MSP jest identyfikacja kluczowych obszarów konsumpcji i konsumentów preferujących parametry jakościowe nabywanych dóbr, a szczególnie żywności. W ślad za tym można przyjąć wybór i realizację strategii wyróżnienia oferty, a także koncentracji na produkcie i rynku przez mikro, małe i średnie, lokalne przedsiębiorstwa jako adekwatne do uwarunkowań. Krytycznym czynnikiem może być wiedza i umiejętności przedsiębiorców w zakresie: zarządzania strategicznego, wypracowania oraz realizacji właściwej strategii marketingowej [Blikle, 2015]27.

\section{Literatura}

Blikle A. 2015 Firmy rodzinne w gospodarce Polski i swiata, [w:] Konkurencyjnośc mikro, malych iśrednich przedsiębiorstw. Gospodarka konkurencyjnej Polski, Kancelaria Prezydenta, Forum Debaty Publicznej, dokument elektroniczny, tryb dostępu: [www.prezydent.pl/ .../fdp_konkurencyjnosc_mikro_malych_i_srednich, data wejścia: 25.11.2015].

Brodzicki T. 2014 Przestrzenne aspekty wzrostu gospodarczego. Przeglad literatury teoretycznej, „Working Paper”, nr 4 (15).

Damasiewicz B., 2015, Dlaczego Polska nie wygrywa w gospodarcaych mistrzostwach swiata?, [w:] Konkurencyjność mikro, malych $i$ średnich przedsiębiorstw, Forum Debaty Publicznej, dokument elektroniczny, tryb dostępu: [https://www.google.pl/url?sa=t\&rct $=\mathrm{j} \& \mathrm{q}=\&$ esrc $=\mathrm{s} \&$ source $=$ web\&cd $=9 \& v e d=0$ ahUKEwiUjofPpanJ AhVlj3IKHfe UChQQFghPMAg\&url=http $\% 3 \mathrm{~A} \% 2 \mathrm{~F} \% 2 \mathrm{Fwww}$.prezydent.pl $\% 2 \mathrm{Fdownload} \% 2$ Fgfx $\% 2$ Fprezydent $\% 2 \mathrm{Fpl} \% 2 \mathrm{Fdefaultaktualnosci} \% 2 \mathrm{~F} 3806 \% 2 \mathrm{~F} 3 \% 2 \mathrm{~F} 1 \% 2 \mathrm{Ffdp} \_\mathrm{k}$ onkurencyjnosc_mikro_malych_i_srednich_przedsiebiorstw.pdf\&usg=AFQjCN FTXlepA3cspV1JRH_E_1GCJLtzwA\&cad=rja, data wejścia: 25.11.2015].

Dokument elektroniczny, tryb dostępu: [www.590powodow.pl, data wejścia: 10.08.2015].

Dokument elektroniczny, tryb dostępu: [www.erov.be/documenten/gazdecki_ goldmann.ppt, data wejścia: 20.05.2015].

Etnocentryzm konsumencki na rynku produktón symnościonych. Stan i perspektywy rozzwoju 2014, „Marketing i Rynek”, nr 6, dokument elektroniczny, tryb dostępu: [http://www.researchgate.net/publication/273961342_etnocentryzm_konsumen cki_mir_nr_6_2014, data wejścia: 29.11.2015].

Florek M. 2013 Podstany marketingu terytorialnego, Wydawnictwo Uniwersytetu Ekonomicznego w Poznaniu, Poznań.

${ }^{27}$ Jedną z przyczyn takiego stanu rzeczy może być to, że znacząca część MSP to firmy rodzinne. Ich wkład w tworzenie PKB i miejsc pracy nie budzi watpliwości, w przeciwieństwie do nadal względnie niskich umiejętności i doświadczenia w zarządzaniu. Należy odnotować, że perspektywa nowych miejsc pracy (biorąc pod uwage np. ich koszt) istnieje przede wszystkim w firmach rodzinnych, warto zatem poszukiwać takich strategii konkurowania, które dają im szansę na rynku międzynarodowym. Zob. [np.: Blikle, 2015]. 
Gierszewska G. 2014 Analiza strategiczna przedsiebiorstwa, Wydawnictwo PWE, Warszawa.

Głód W. 2015 Internacjonalizacja w procesie rozwoju matych $i$ średnich przedsiębiorstw - uybrane wyniki badań empirycznych, dokument elektroniczny, tryb dostępu: [www.ue.katowice.pl/ uploads/media/6_W.Glod_Internacjonalizacja_w_procesie, data wejścia: 24.11.2015].

Hereźniak M. 2011 Marka narodowa. Jak skutecznie budowaí wizerunek i reputacje kraju, Wydawnictwo PWE, Warszawa.

Leśniewski M. A. 2015 Konkurencyjność miękea przedsiębiorstw, Wydawnictwo Difin, Warszawa.

Łojewski S. 2008 Ekonomia zasobów a zrównoważony rozwój, „Woda - Środowisko Obszary Wiejskie", tom 2.

Łyżwa E. 2014 Innowacyjność przedsiębiorstw a konkurencyjnośc regionów, Wydawnictwo Uniwersytetu Jana Kochanowskiego, Kielce.

Maćkowiak H. 2013 Zróżnicowanie struktury handlu zagranicznego Polski w ujęciu regionalnym oraz konkurencyjność eksportowa regionów, Wydawnictwo Bogucki, Wydawnictwo Naukowe, Poznań.

Magrett J. 2014 Zrozumieć Michaela Portera, Wydawnictwo MT Biznes, Warszawa.

Marketing eksportowy - poradnik dla malych i średnich przedsiębiorców 2014, PARP, Warszawa, dokument elektroniczny, tryb dostępu: [http://www.parp.gov.pl/files/ 74/81/713/21853.pdf, data wejścia: 25.11.2015].

Międzynarodowa konkurencja - kluczowe wyzwania dla polskich przedsiębiorców, 2006, Wydawnictwo Harvard Business Review Polska, dokument elektroniczny, tryb dostępu: [/webapp01.ey.com.pl/EYP/WEB/eycom_download.nsf/resources/Index/ \$FILE/Indeks_Przedsiebiorczosci06, data wejścia: 25.11.2015].

Misala J. 2010 Historia rozwoju teorii i polityki konkurencyjności międzynarodowej, Wydawnictwo Oficyna SGH, Warszawa.

Mruk H., Stępień B. 2013 Tworzenie wartości dla klienta z.perspektywy konsumentów i przedsiębiorców, Wydawnictwo PWE, Warszawa.

Nowińska-Łaźniewska E. 2013 Konkurencyjność regionalna w czasie i przestrz̨eni, Wydawnictwo Uniwersytetu Ekonomicznego w Poznaniu, Poznań.

Obłój K. 2014 Strategia organizacji, Wydawnictwo PWE, Warszawa.

Pierścionek Z. 2003 Strategie konkurencji i roz̧woju prẓedsiębiorstwa, Wydawnictwo PWN, Warszawa.

Porter M.E. 2010 Strategia konkurencii, Wydawnictwo MT Biznes, Warszawa.

Porter M.E. 2012 O strategii, Wydawnictwo ICAN Institute, Warszawa.

Przedsiebiorstwa wysokiego wrrostu w Polsce 2014, PARP, Warszawa, dokument elektroniczny, tryb dostępu: [http://badania.parp.gov.pl/images/badania/przedsie biorstwa_ wysokiego_wzrostu_w_Polsce, data wejścia: 26.11.2015].

Raport o stanie sek.tora malych $i$ średnich przedsiebiorstw w Polsce, 2015, PARP, dokument elektroniczny, tryb dostępu: [http://badania.parp.gov.pl/images/badania/ROSS_ 2013_2014.pdf, data wejścia: 25.11.2015].

Rymarczyk J. 2012 Strategie konkurencji przedsiębiorstwa międynarodowego, „Prace i Materiały Instytutu Handlu Zagranicznego Uniwersytetu Gdańskiego”, nr 31.

Sawin S. 2015 W poszukiwaniu tajemniczych mistrzów polskiej przedsiębiorczości, [w:] Konkurencyjność mikero, małych $i$ średnich. Gospodarka konkurencyjnej Polski, Kancelaria 
Prezydenta, Forum Debaty Publicznej, dokument elektroniczny, tryb dostępu: [www.prezydent.pl/.../fdp_konkurencyjnosc_mikro_malych_i_srednich, data wejścia: 25.11.2015].

Szromnik A. Wolanin-Jarosz E. 2014 Etnocentryzm konsumencki na zglobalizowanym rynku caynniki i procesy ksztattowania. cz.1., „Marketing i Rynek”, nr 4, dokument elektroniczny, tryb dostępu: [http://www.pwe.com.pl/files/1276809751/ file/mir_04_ 2014_szromnik.pdf, data wejścia: 25.11.2015].

Szymański W. 2015 Świat i Polska wobec nyzwań, Wydawnictwo Difin, Warszawa.

Tendencje zachowan konsumenckich na regionalnym rynku 2010, Wydawnctwo Naukowe Uniwersytetu Szczecińskiego, Szczecin, dokument elektroniczny, tryb dostępu: [www.researchgate.net/publication/264464411_Preferencje_konsumentw_w_za kresie_wyboru_miejsca_nabywania_ywnoci, data wejścia: 25.11.2015].

Teorie i podejścia badawcze w nauce o stosunkach miedsynarodowych 2015, R. Zięba, S. Bieleń, J. Zając (red.), Wydawnictwo Uniwersytetu Warszawskiego, Warszawa.

Wolanin-Jarosz E. 2015 Etnocentryzm konsumencki w środowisku miedsynarodonym. Studium rynkowe Euroregionu Karpackiego, Wydawnictwo Difin, Warszawa.

Wspótczesne teorie ekonomicz̧ne 2012, M. Ratajczak (red.), Wydawnictwo Uniwersytetu Ekonomicznego w Poznaniu, Poznań.

Zaucha J. 2012 Synteza aktualnego stanu wiedzy dotyczacej rozpoju sustensywnego i spójności terytorialnej w planowaniu przestrzennym, [w:] Planowanie przestrzenne w rozwoju żównoważonym. Inspiracje i dobre praktyki Ecoregionu, Wydawnictwo Uniwersytetu Gdańskiego, Gdańsk.

Żakowska-Biemans S. 2012 Żywność tradycyjna ₹. perspektywy konsumentów, „Żywność. Nauka, Technologia. Jakość", nr 3 (82), dokument elektroniczny, tryb dostępu: [http://www.pttz.org/zyw/wyd/czas/2012,\%203\%2882\%29/01_Zakowska.pdf, data wejścia: 25.11.2015]. 